\title{
KRONIEK RECHTSPRAAK
}

\section{Kroniek rechtspraak strafrecht}

\author{
Prof. mr. P.A.M. Mevis E mr. drs. L. Postma*
}

In de vorige Kroniek rechtspraak strafrecht (TvGR 2017, p. 640-658) bespraken wij de relevante rechtsontwikkelingen in wetgeving en rechtspraak tot en met 31 augustus 2017. In deze Kroniek staan de belangrijkste ontwikkelingen vanaf die datum tot 1 november 2019 centraal. Bij een aantal thema's is sprake van een vervolg van de ontwikkelingen. Ten aanzien van de voor het strafrecht en de geestelijke gezondheidszorg zeer relevante wetgeving van de Wvggz, de Wzd en de Wfz, mede strekkende tot vervanging van de Wet Bopz, zoals een en ander per 1 januari 2020 nader in werking treedt, volstaan wij in de kroniek met verwijzing naar de verschillende bijdragen die in de onlangs verschenen aflevering van dit tijdschrift daaraan zijn gewijd. ${ }^{1}$

\section{Wijzigingen strafbepalingen Wet BIG in werking}

De in de vorige kroniek besproken gewijzigde/ nieuwe artikelen 96 en 98a Wet BIG zijn op 1 april 2019 in werking getreden. ${ }^{2}$ De wijziging van artikel 96 Wet BIG, waarin dezelfde terminologie is gehanteerd als in artikel $300 \mathrm{Sr}$ ('schade' is vervangen door het ruimere begrip 'benadeling'), moet volgens de memorie van toelichting zo veel mogelijk hinder-

* Paul Mevis is hoogleraar strafrecht en strafprocesrecht aan de Erasmus Universiteit Rotterdam. Liselotte Postma is wetenschappelijk docent strafrecht en strafprocesrecht aan de Erasmus Universiteit Rotterdam.

1 Zie over enig overgangsrecht t.a.v. de maatregel van plaatsing in een psychiatrisch ziekenhuis (art. $37 \mathrm{Sr}$ dat per 1 januari 2020 vervalt), inmiddels Hof Den Haag 4 november 2019, ECLI:NL:GHDHA:2019:2919.

2 Stb. 2018, 260, inwerkingtreding 1 april 2019 (Stb. 2019, 111). nissen voor effectieve handhaving wegnemen. ${ }^{3}$ Op grond van artikel 98a Wet BIG zijn de mogelijkheden voor de ontzetting uit het recht een of meer beroepen op het terrein van de gezondheidszorg uit te oefenen, uitgebreid. De Wijzigingswet bevat zelf geen bepalingen van overgangsrecht. Dat betekent dat de algemene regeling van artikel 1 lid 2 Sr van toepassing is: voor zover de wetswijziging blijk geeft van een gewijzigd inzicht in de strafbaarheid bij de wetgever c.q. de straf wordt verhoogd of uitgebreid, blijft op gedragingen die voor de inwerkingtreding zijn begaan de oude regeling van toepassing. In zoverre zullen vervolgingen en veroordelingen op grond van deze nieuwe artikelen nog wel even uitblijven. Op rechtspraak.nl zijn er dan ook tot nu toe geen te vinden.

\section{Vervolg Haagse borstendokter en 'neparts'}

In deze kroniekperiode heeft de zaak tegen de Haagse borstendokter een vervolg gekregen. De rechtbank had de borstendokter in 2014 vrijgesproken omdat, hoewel de arts een aantal verwijten kon worden gemaakt over de kliniekvoering en nazorg, die volgens de rechtbank niet zodanig zwaarwegend waren dat de arts een beroep op de medische exceptie moest worden ontzegd. ${ }^{4}$ Drie jaar later wil Hof Den Haag van de medische exceptie niets weten wat de door de gynaecoloog uitgevoerde borstoperaties betreft. ${ }^{5}$ Het hof is, anders dan de rechtbank, van

3 Kamerstukken II 2016/17, 34629, 3, p.25.

4 Rb. Den Haag 30 oktober 2014, ECLI:NL:RBDHA: 2014:13243.

5 Hof Den Haag 30 november 2017, ECLI:NL:GHDA: 2017:3382. 
oordeel dat de arts zijn ingrepen niet volgens de regelen der kunst heeft verricht en veroordeelt hem tot een gevangenisstraf voor de duur van twee jaar, waarvan een jaar voorwaardelijk met een proeftijd van drie jaar en de bijzondere voorwaarde dat hij gedurende de proeftijd geen medische (be)handelingen verricht. Eerder was de man door de tuchtrechter al voor het leven geschrapt uit het BIG-register. ${ }^{6}$ Daarmee is waarschijnlijk wel al een eind gekomen aan het handelen van deze man in de gezondheidszorg en waarschijnlijk ook aan de strafvervolging in deze zaak; ondanks andersluidende berichten in de media, ${ }^{7}$ lijkt geen beroep in cassatie te zijn ingesteld of doorgezet.

In de Kroniek uit 2016 bespraken wij een zaak over een 'neparts' die was ontmaskerd en veroordeeld vanwege diverse strafbare feiten waarbij het merendeel van handelen op grond van de wet is voorbehouden aan medisch geschoolde specialisten. ${ }^{8} \mathrm{Bij}$ een van zijn patiënten had hij telkens de indruk gewekt een ervaren arts te zijn, haar geadviseerd een operatie te ondergaan in China vanwege de diagnose borstkanker, en zich daarvoor 60.000 euro laten betalen. Bij thuiskomst bleken er geen kankerwerende apparaatjes' in de borsten van het slachtoffer te zijn geplaatst. Het slachtoffer bleek ook geen kanker te hebben. Hof Arnhem-Leeuwarden legde dezelfde straf op als de rechtbank: drie jaar gevangenisstraf waarvan een jaar gevangenisstraf voorwaardelijk, met een proeftijd van vijf jaar en als bijzondere voorwaarde een verbod om handelingen op het gebied van de individuele gezondheidzorg te verrichten ter zake van oplichting. ${ }^{9}$ In cassatie is de vraag aan de orde of de patiënte zelf niet te naïef is geweest. ${ }^{10}$ De Hoge Raad overweegt, verwijzend

6 CTG 23 juni 2011, ECLI:NL:TGZCTG:2011:YG1358, GJ 2015/3.

7 www.medischcontact.nl/nieuws/laatste-nieuws/ artikel/veroordeelde-borstendokter-naar-hogeraad.htm.

8 Rb. Gelderland 25 juni 2015, ECLI:NL:RBGEL: 2015:4169.

9 Hof Arnhem-Leeuwarden 30 juni 2017, ECLI:NL:GHARL:2017:5470.

10 HR 23 april 2019, ECLI:NL:HR:2019:652, NJ 2019/194. naar HR 20 december 2016, ECLI:NL:HR:2016:2892, dat oplichting in de zin van artikel 326 lid 1 Sr inderdaad niet aan de orde is wanneer het slachtoffer - gelet op alle omstandigheden van het geval, waaronder de eigen gedragingen en kennis van zaken de in een bepaalde gedraging van de verdachte besloten liggende onjuiste voorstelling van zaken had moeten doorzien. Maar de Hoge Raad oordeelt ook dat het oordeel van het hof dat een dergelijke situatie zich in deze zaak niet voordoet, geen blijk geeft van een onjuiste rechtsopvatting en evenmin onbegrijpelijk is. Dat wordt volgens de Hoge Raad niet anders door de omstandigheid dat het slachtoffer, nadat de verdachte een 'vrijwel zeker kwaadaardig' knobbeltje in haar borst had geconstateerd, deelnam aan een bevolkingsonderzoek naar borstkanker waarbij niets werd gevonden. Verdachte heeft namelijk bij het slachtoffer op verschillende manieren het vertrouwen gewekt dat hij over medische kennis beschikte. Bovendien heeft hij voorafgaand aan het bevolkingsonderzoek aan haar medegedeeld 'dat ze met de inferieure apparatuur in Nederland de door hem geconstateerde knobbel niet zouden zien'.

\section{Medisch beroepsgeheim en vorderen gegevens}

Voor wat betreft de wetgeving op het immer gevoelige en nog steeds in beweging zijnde onderwerp van de bescherming van het beroepsverschoningsrecht is van belang dat per 1 oktober 2018 de (laatste) wijziging van artikel $98 \mathrm{~Sv}$ in werking is getreden. ${ }^{11}$ Daarmee heeft de bescherming van het beroepsverschoningsrecht in het (bestaande) Wetboek van Strafvordering in elk geval z'n beslag gekregen dat de bescherming tegen inbreuken daarop steeds via de rechter-commissaris lopen. Beklag is mogelijk via de procedure van artikel 552a Sv. De r-c kan zich doen bijstaan door een vertegenwoordiger van de beroepsgroep, in de medische zaken de Onafhankelijk Deskundige Arts (de ODA

11 Wet van 4 juli 2018, Stb. 2018, 264, inwerkingtreding 1 oktober 2018 (Stb. 2018, 265). 
uit Stcrt. 2016, 57996). De regeling in het conceptWetboek van Strafvordering uit de operatie Modernisering strafvordering is nog wat meer uitgeschreven, met name op het punt van het afgeleid verschoningsrecht en de waarborgen bij het doorzoeken van (grote) hoeveelheden documenten en gegevens na de inbeslagneming. ${ }^{12}$ Er bestaat onzes inziens weinig bezwaar tegen om deze uitgangspunten ook nu reeds in acht te nemen. In andere wetgeving staat dat medisch beroepsgeheim eerder onder druk. De Wet foetaal weefsel (in verband met het mogelijk maken van het bewaren en gebruiken van foetaal weefsel ten behoeve van de opsporing en vervolging van ernstige zedenmisdrijven) is op 27 april 2019 in werking getreden. ${ }^{13}$ Deze wet makkt het voor een arts mogelijk (niet verplicht) om foetaal weefsel afkomstig van een slachtoffer van bepaalde zedenmisdrijven, ten behoeve van de opsporing daarvan te gebruiken, vanaf de leeftijd van 16 jaren uitsluitend met toestemming van het (wilsbekwame) slachtoffer. De MvT merkt enerzijds uitdrukkelijk op dat het niet de bedoeling is de arts te verplichten om het beroepsgeheim te doorbreken. Anderzijds begint de MvT met een veelzeggende toonzetting: 'Zedenmisdrijven als verkrachting, aanranding of ontucht roepen in de samenleving veel gevoelens van woede en afschuw op. Ieder slachtoffer van een zedenmisdrijf verdient steun en bescherming. Deze steun en bescherming bestaan deels uit de vervolging van de vermoedelijke dader. ${ }^{14}$ Misschien is het dan toch goed te herhalen

12 Zie over de problematiek van het adequaat selecteren van gegevens die wel of niet onder het verschoningsrecht van een arts vallen de recente conclusie van A-G Knigge van 1 oktober 2019, ECLI:NL:PHR:2019:971. Het gaat in deze zaak om het van heel veel artsen afgeleide verschoningsrecht van een ambulancevervoerder. Daardoor kan alleen door van de inhoud kennis te nemen worden vastgesteld van wie de medische informatie afkomstig is of voor wie die informatie is bestemd, dus wie de verschoningsgerechtigden allemaal zijn. De A-G zet uiteen hoe te handelen. Een arrest van de Hoge Raad is nog niet voorhanden.

13 Wet van 27 maart 2019, Stb 2019, 138. Inwerkingtreding Stb. 2019, 139.

14 Kamerstukken II 2017/18, 34893, 3. dat een arts zich niet zozeer tegenover de strafvordering op zijn beroepsgeheim c.q. verschoningsrecht beroept (in de zin van in stelling brengt'), maar hij veeleer de erkenning ervan in de strafvordering zelf (art. $218 \mathrm{~Sv}$ ) onder de aandacht van de organen van de strafvordering brengt tot wie dergelijke bepalingen in de eerste plaats zijn gericht, al is het dan ook zo dat de aanspraak van de patiënt / het slachtoffer op strafrechtelijke rechtshandhaving door opsporing, vervolging en berechting onder omstandigheden grond kan zijn om dat verschoningsrecht te doorbreken. ${ }^{15}$

Juist vanwege de 'gretigheid' van de wetgever is HR 10 april 2018, NJ 2018/435, bepaald van enig belang voor de reikwijdte van het verschoningsrecht. ${ }^{16} \mathrm{Het}$ gaat in die zaak om een vordering gevoelige gegevens als bedoeld in artikel 126nf/126uf Sv, te weten de camerabeelden van wachtruimte en toegangspaden in een ziekenhuis. De beelden zijn gevorderd om de identiteit te kunnen achterhalen van een man die mogelijk dader is van een (vermoedelijk) begane mishandeling. Het slachtoffer daarvan zag in de wachtruimte een man die zij meende te herkennen als dader. De rechtbank oordeelde kort gezegd dat beelden die opnames bevatten van hetgeen zich in dergelijke ruimtes afspeelt, niet kunnen gelden als 'wetenschap' die aan een arts in het kader van zijn beroepsuitoefening is 'toevertrouwd' als bedoeld in artikel 218 Sv. De beelden vallen daarmee (ook) niet onder het (afgeleide) verschoningsrecht van het ziekenhuis. De Hoge Raad oordeelt principieel anders. Hij zet (nogmaals) uitdrukkelijk uiteen dat het verschoningsrecht van de arts zich uitstrekt tot gegevens die betrekking hebben op de behandeling en de verzorging van de aan zijn zorgen toevertrouwde patiënten, alsmede tot gegevens die hem in zijn hoedanigheid zijn medegedeeld of waarvan hij in zijn hoedanigheid heeft kennis gekregen, en waarvan de openbaarmaking het vertrouwen zou beschamen dat de patiënten met het oog op zijn hulpverlenende taak in hem moeten kunnen stellen. In dat licht overweegt hij vervolgens dat de rechtbank heeft

15 HR 5 juli 2011, NJ 2011/416 m.nt. Legemaate.

16 HR 10 april 2018, ECLI:NL:HR:2018:553, NJ $2018 / 435$. 
miskend dat camerabeelden waaruit de identiteit van een patiënt of van het bestaan van een (toekomstige) hulpverleningsrelatie valt af te leiden omdat zij de bezoeker van een bepaalde arts of een bepaalde behandelafdeling van een ziekenhuis herkenbaar in beeld brengen, aldus ook onder het verschoningsrecht vallen. Dat op de desbetreffende camerabeelden ook bezoekers en begeleiders te zien zijn en dat de plaatsen waar die camerabeelden zijn gemaakt voor eenieder toegankelijk zijn, maakt dat niet anders. Gelet op de strekking van het verschoningsrecht (zich vrij tot een hulpverlener moeten kunnen wenden) is het verschoningsrecht ook (al) van toepassing als iemand (in een ziekenhuis) op weg is naar een behandelafdeling. ${ }^{17}$ De zaak illustreert de verleidelijkheid van het gebruik van nu eenmaal reeds aanwezige camerabeelden.

Van 'uitzonderlijke omstandigheden' die maken dat het belang van waarheidsvinding zwaarder dient te wegen dan het verschoningsrecht is sprake in de beschikking van Rechtbank Midden-Nederland 17 april 2018 op het klaagschrift van de Stichting Regionale Ambulance Voorziening provincie Utrecht (RAVU). ${ }^{18}$ De officier van justitie had geluidsfragmenten gevorderd van 112-meldingen vanwege een onderzoek naar een (destijds) paar maanden oude baby die tweemaal is gereanimeerd en met spoed is opgenomen in het Meander Ziekenhuis. De vader van de baby wordt verdacht van een tweetal pogingen tot verwurging van het kindje. Hij heeft wroeging gekregen en zich ruim anderhalf jaar nadat de feiten hebben plaatsvonden gemeld bij de politie. De rechtbank is van mening dat geluidsfragmenten van 112-meldingen onder het verschoningsrecht vallen, maar dat er in dit geval sprake is van uitzonderlijke omstandigheden die doorbreking rechtvaardigen. Het gaat immers om twee zeer ernstige delicten begaan jegens een jong

17 Vgl. HR 16 juni 2009, NJ 2009/603: telefoongesprek met een advocaat om een afspraak te maken om te zien of een rechtsbijstandsrelatie tot stand kan komen, wordt door het verschoningsrecht beschermd.

18 Rb. Midden-Nederland 17 april 2018, ECLI:NL:RBMNE:2018:1566. en kwetsbaar slachtoffer en er is sprake van een zwaarwegend belang tot het doen van effectief en onafhankelijk onderzoek. De geluidsfragmenten zouden meer duidelijkheid kunnen geven over de omstandigheden waaronder de baby tot tweemaal toe in het ziekenhuis is opgenomen, wat daarvan mogelijk de aanleiding is geweest en wie daarvoor verantwoordelijk is. Alle direct betrokkenen bij de baby, te weten haar voogd, moeder en ook verdachte, haar vader, hebben toestemming gegeven tot het verstrekken van de geluidsfragmenten. Het horen van getuigen zou, nog steeds volgens de rechtbank, niet tot hetzelfde resultaat kunnen leiden als het afluisteren van de fragmenten: de gebeurtenissen hebben meer dan twee jaar geleden plaatsgevonden en er was sprake van een panieksituatie, waarbij nog geen verdenking was van een misdrijf. Het niet openbaren van de geluidsfragmenten belemmert volgens de rechtbank het doen van een effectief en onafhankelijk onderzoek in deze zaak. De uitgebreide motivering maakt de beslissing gemakkelijk(er) begrijpelijk.

Ook in de beslissing van de r-c in Rechtbank Limburg 22 mei 2019, wordt het verschoningsrecht doorbroken. Het betreft een strafzaak die de nodige media-aandacht heeft gekregen. ${ }^{19}$ Thijs H. heeft zich in de namiddag gemeld bij Stichting Mondriaan, een instelling voor geestelijke gezondheidszorg, met bloed op zijn kleding. Hij vertelde daarbij dat hij een aantal uren op de Brunssumerheide had gezworven. Op die heide was die dag een dubbele moord gepleegd. Een aantal dagen eerder was het levenloze lichaam van een vrouw aangetroffen in de Scheveningse Bosjes. Verdachte is op een gesloten afdeling geplaatst, maar het is hem twee keer gelukt de instelling te ontvluchten. De zorginstelling heeft vervolgens contact opgenomen met de politie om 'meer slachtoffers te voorkomen'. Thijs H. wordt ervan verdacht drie mensen van het leven te hebben beroofd. Hij ontkent, getuigen zijn er niet en medewerkers van de zorginstelling blijken niet erg bereid te zijn om te verklaren. De officier van justitie heeft

19 Rb. Limburg 22 mei 2019, ECLI:NL:RBLIM: 
op grond van artikel 126nf Sv van de zorginstelling de afgifte gevorderd van alle opgenomen camerabeelden van de middag dat verdachte zich bij Mondriaan gemeld had tot en met de ochtend dat hij de instelling voor de tweede keer kon ontvluchten. Door middel van deze camerabeelden zou vastgesteld kunnen worden welke kleding verdachte droeg toen hij zich heeft gemeld, in welke staat deze kleding was, welke spullen verdachte bij zich had en welke kleding hij aan had toen hij naar de instelling werd teruggebracht en voor de tweede keer kon vluchten. De geneesheer-directeur van de instelling heeft te kennen gegeven zich ten aanzien van de camerabeelden te beroepen op zijn verschoningsrecht. De $r-c$ is van oordeel dat in dit onderzoek naar de gewelddadige dood van drie mensen het beroep op het verschoningsrecht moet wijken voor het belang van de waarheidsvinding. Ten eerste vanwege het feit dat door toedoen van de media algemeen bekend is geworden dat verdachte zich tot hulpverlening heeft gewend kort nadat de dodingen hebben plaatsgevonden en dat feit in deze zaak dus geen bescherming meer behoeft. Ten tweede omdat slechts een zeer beperkte inbreuk zou worden gemaakt. Beelden van andere patiënten zouden niet (herkenbaar) worden geopenbaard. Ten slotte omdat naar het oordeel van de $\mathrm{r}-\mathrm{c}$ de benodigde informatie niet op een andere, minder ingrijpende manier verkregen kan worden. We volstaan op deze plaats met de vaststelling dat de beslissing van de $\mathrm{r}$-c de opsporing in deze strafzaak betreft. De zaak illustreert daarnaast de worsteling waarmee zorginstellingen in dergelijke zaken te maken kunnen krijgen, inclusief stevige verwijten van publiek en media achteraf.

\section{Fraude in de zorg}

De zorg om financiering van de zorg maakt dat fraude in de zorg hard wordt aangepakt. In de eerdere Kroniek vermeldden we in dit verband de totstandkoming van, ook hiervoor reeds aangestipt, het Convenant inzet onafhankelijk deskundige arts bij signalen en verdenkingen van fraude in de zorg, gepubliceerd in Stcrt. 2016, 57996. Een voorbeeld van de versterkte aanpak uit de huidige kroniekperiode is het conceptwetsvoorstel bevorderen samenwerking en rechtmatige zorg. ${ }^{20}$ Dit conceptwetsvoorstel beoogt wettelijke grondslagen te creëren voor het uitwisselen van gegevens tussen partijen die een rol hebben in de bestrijding van fraude in de zorg. De 'harde lijn van aanpak' is in de rechtspraak te herkennen. Eén strafzaak gaat om fraude met persoonsgebonden budgetten (pgb's) en Zorg in Natura. ${ }^{21}$ Terecht staat een aandeelhouder en bestuurder van een bedrijf dat actief is in de gezondheidszorg. ${ }^{22}$ Zij wordt door Hof Den Haag veroordeeld vanwege het deelnemen aan twee verschillende criminele organisatie als bedoeld in artikel $140 \mathrm{Sr}$, welke organisaties het plegen van verschillende misdrijven tot oogmerk hadden (oplichting, valsheid in geschrift, witwassen en het opzettelijk nalaten tijdig de benodigde gegevens te verstekken als bedoeld in art. 227b Sr). Het hof overweegt dat bij beide organisaties sprake was van een onderlinge rolverdeling tussen de verschillende verdachten, met als doel zichzelf te verrijken met onterecht verkregen gelden. Verdachte en haar mededaders hebben volgens het hof op schaamteloze wijze misbruik gemaakt van het pgb-systeem en het systeem waarbij Zorg in Natura wordt verleend. Voorts hebben de verdachte en haar mededaders misbruik gemaakt van een zeer kwetsbare en hulpbehoevende groep in de samenleving. Het hof acht 36 maanden gevangenisstraf op z'n plaats en legt daarvan, vanwege een correctie voor een overschrijding van de redelijke termijn, 34 maanden op. Het hof gaat daarbij uitdrukkelijk voorbij aan het feit dat deze straf, zeker nu de partner van de verdachte in deze zaak ook tot een langdurige gevangenisstraf wordt veroordeeld, ingrijpende

20 Zie voor het ambtelijk concept van 7 juni 2018: www.internetconsultatie.nl/rechtmatigezorg.

21 Hof Den Haag 15 september 2017, ECLI:NL:GHDHA: 2017:2649.

22 Een vergelijkbare strafzaak over een criminele organisatie die stelselmatig pgb-fraude pleegde is Rb. Limburg 10 november 2017, ECLI:NL:RBLIM:2017:10933. Zie over pgb-fraude ook de volgende vonnissen van Rb. Rotterdam: ECLI:NL:RBROT:2018:9700/9702/ 9703. 
gevolgen heeft voor de vier minderjarige kinderen - onder wie hun zieke dochter - die van de zorg van de verdachte en haar partner afhankelijk zijn. De Hoge Raad moet de opgelegde straf wederom corrigeren tot 32 maanden, vanwege overschrijding van diezelfde redelijke termijn in de cassatiefase. ${ }^{23}$ Aangezien het cassatieberoep voor het overige wordt verworpen, doet het gebrek aan voortvarendheid van de kant van justitie afbreuk aan de 'harde lijn' van fraudebestrijding.

In een strafzaak berecht door Rechtbank Overijssel op 5 november 2018, heeft de verdachte in haar hoedanigheid van bestuurder van een stichting, dus als feitelijk leidinggevende in de zin van artikel 51 $\mathrm{Sr}$, aanzienlijke geldbedragen aan pgb-gelden ontvangen voor zorgverlening. ${ }^{24}$ De gelden kwamen binnen op de rekening van de stichting doordat verdachte verantwoordingsformulieren van verschillende cliënten valselijk heeft opgemaakt dan wel heeft doen opmaken door hierop bedragen aan pgb-geld in te vullen, terwijl de te verlenen zorg niet werd verleend. Verdachte heeft de pgb-gelden deels aangewend voor de aanschaf van materiële zaken voor cliënten, zoals wasmachines, fietsen, abonnementen op een dierentuin en vakanties. Zodoende was er, aldus het vonnis, sprake van valsheid in geschrifte en gewoontewitwassen. Op gelijksoortige argumenten als het hof in de boven aangehaalde zaak (aantasting van het fundament van het pgbsysteem (in dit geval: 'van binnenuit' door de deelnemer daaraan), misbruik van het vertrouwen van de kwetsbare en hulpbehoevenden cliënten van verdachte en het op oneigenlijke wijze beschikken over gemeenschapsgelden) komt de rechtbank tot een gevangenisstraf van twaalf maanden, waarvan negen maanden voorwaardelijk met een proeftijd van twee jaar en, als bijkomende straf, een beroepsverbod tot het uitoefenen van enig beroep in de zorgverlening voor een termijn van vijf jaar. In deze gevallen van fraude zorgen de betreffende bepalingen in het Wetboek van Strafrecht voor de mogelijkheid van ontzetting uit het beroep als bijko-

23 HR 2 juli 2019, ECLI:NL:HR:2019:1077.

24 Rb. Overijssel 5 november 2018, ECLI:NL:RBOVE: 2018:4207. mende straf. De gelijke voorzieningen in artikel 96 lid 3 Wet BIG en in het (nieuwe) artikel 98a Wet BIG hebben eerder betrekking op 'verkeerde zorg'.

\section{Vrijspraak dood door schuld zorginstelling}

Het vonnis van Rechtbank Oost-Brabant van 20 mei 2019 betreft de betrekkelijk uitzonderlijke situatie dat een zorginstelling op grond van artikel $51 \mathrm{Sr}$ als rechtspersoon strafrechtelijk is vervolgd. ${ }^{25}$ Zes jaar na overlijden van een patiënte vanwege (acuut) hartfalen als gevolg van het nalaten van zowel betrokken artsen als verpleegkundig personeel na behandeling met het risicovolle geneesmiddel Clozapine, heeft het Openbaar Ministerie op initiatief van de inspectie besloten om de GGZ-instelling waar de patiënte opgenomen was strafrechtelijk te vervolgen wegens dood door schuld (art. 307 Sr). In 2015 hebben de betrokken afdelingspsychiater en arts in opleiding tot psychiater (AIOS) een berisping respectievelijk waarschuwing opgelegd gekregen door de tuchtrechter. ${ }^{26} \mathrm{Er}$ is volgens het $\mathrm{OM}$ door de GGZ een strafrechtelijke grens overschreden. De GGZ zou nalatig en in strijd met de zorgvuldigheidseisen hebben gehandeld door niet in de voorwaarden voor verantwoorde zorg te voorzien. De rechtbank concludeert dat de betrokken artsen en het verplegend personeel niet hebben gehandeld zoals van redelijk handelende en bekwame medische professionals mocht worden verwacht: hun gedragingen leveren een schending van hun zorgplicht op. Volgens de rechtbank staat vast dat de patiënte door een opeenstapeling van tekortkomingen in de zorg is overleden. Toch komt de rechtbank tot de conclusie dat de GGZ-instelling in dit geval haar taak, te weten het scheppen van voorwaarden voor een kwalitatieve goede zorg voor haar patiënten en haar organisatie zodanig in te richten dat de professional zijn taak naar behoren kan uitoefenen, naar behoren heeft uitgevoerd.

25 Rb. Oost-Brabant 20 mei 2019, ECLI:NL:RBOBR: 2019:2829.

26 RTG 25 maart 2015, ECLI:NL:TGZREIN:2015:27. 
Volgens de rechtbank kan niet worden gesteld dat de GGZ grovelijk, althans met aanmerkelijke verwaarlozing van de te betrachten zorgvuldigheid die redelijkerwijs gesteld mocht worden, heeft gehandeld dan wel nagelaten heeft te handelen. In zijn annotatie bij dit vonnis eerder in dit tijdschrift noemt Hubben het opvallend dat de rechtbank bij de beoordeling van de tekortkomingen nergens aansluiting zoekt bij het kader dat door de Hoge Raad in het zogenoemde 'Drijfmest-arrest' ${ }^{27}$ is ontwikkeld bij de beoordeling van de vraag wanneer een gedraging redelijkerwijze aan een rechtspersoon kan worden toegerekend. Hubben velt een hard oordeel: 'Het vonnis van de rechtbank mist evenwichtigheid, is innerlijk tegenstrijdig en de vrijspraak valt daarom niet te begrijpen. Te hopen valt dat deze manco's in hoger beroep door het gerechtshof worden gerepareerd.28 Naar de uitkomst valt het verschil op met Rechtbank Den Haag 19 december 2002, ECLI:NL:RBSGR:2002:AF2320: vrijspraak arts (die fouten maakte) gegeven de door de zorginstelling veroorzaakte, belabberde werkomstandigheden.

\section{Zedendelicten met patiënt/cliënt}

In de onderhavige kroniekperiode speelden verschillende zaken waarin een beroepsbeoefenaar in de gezondheidszorg of de maatschappelijke zorg, ontucht heeft gepleegd met iemand die zich als patiënt of cliënt aan zijn hulp of zorg heeft toevertrouwd, zoals strafbaar gesteld in artikel 249 lid 2 aanhef en onder 3 Sr. 'Werkzaam in de gezondheidszorg of maatschappelijke zorg' wordt ruim uitgelegd. Aansluitend bij voorbeelden uit de huidige kroniekperiode valt daaronder naast de arts,

27 HR 21 oktober 2003, NJ 2006/328.

28 'Rb. Oost-Brabant 20 mei 2019 (vrijspraak Stichting met betrekking tot dood door schuld van bij de Stichting opgenomen patiënte) m.nt. Hubben', TvGR 2019, p. 419.

29 Rb. Gelderland 22 augustus 2018, ECLI:NL:RBGEL: 2018:3637 en Rb. Den Haag 30 september 2019, ECLI:NL:RBDHA:2019:11475. psychiater, ${ }^{29}$ orthodontist ${ }^{30}$ en de alternatief genezer (zoals een psychometrisch paranormaal genezer, ${ }^{31}$ tantramasseur ${ }^{32}$ of natuurgenezer ${ }^{33}$ ) tevens een 'werkleider' in een instelling voor maatschappelijke zorg, ${ }^{34}$ een oprichter van een evangelische zorgboerderij ${ }^{35}$ en degene die een cliënte van een zorginstelling helpt met het organiseren van het huishouden. ${ }^{36}$ We kunnen slechts een selectie bespreken in deze kroniek.

Eerder in dit tijdschrift is de in 2018 gepubliceerde uitspraak van Hof Amsterdam 20 oktober 2015 verschenen over een psychometrisch paranormaal genezer die is veroordeeld vanwege het verrichten van seksuele handelingen met een patiënte. ${ }^{37}$ Aansluitend bij vaste jurisprudentie van de Hoge Raad dat er in geval van seksueel contact tussen behandelaar en patiënt/cliënt slechts dan geen sprake is van ontucht indien de behandelrelatie bij de seksuele handelingen geen (enkele) rol speelt, in die zin dat bij de patiënt of cliënt sprake is van vrijwilligheid en daarbij enige vorm van afhankelijkheid niet van invloed is geweest, overweegt het hof dat er 'geen sprake [is] van een situatie waarin de behandelrelatie geen rol heeft gespeeld'.

Uit de rechtspraak blijkt dat de toe- of instemming van het slachtoffer met de gedragingen de strafbaarheid van de zorgverlener niet zonder meer opheft. In een uitspraak betreffende een shiatsu-therapeut benadrukt het hof dat instemming van het slachtoffer de wederrechtelijkheid van de handelingen

30 Rb. Overijssel, 26 juli 2018, ECLI:NL:RBOVE: 2018:2688.

31 Hof Amsterdam 20 oktober 2015, ECLI:NL:GHAMS: 2015:5669 TvGR 2019, p. 148, m.nt. Postma.

32 Rb. Midden-Nederland 23 april 2019, ECLI:NL:RBMNE:2019:1709.

33 Rb. Overijssel 8 maart 2018, ECLI:NL:RBOVE: 2018:705.

34 Rb. Zeeland-West-Brabant 1 oktober 2019, ECLI:NL:RBZWB:2019:4299.

35 Rb. Rotterdam 6 maart 2018, ECLI:NL:RBOT: 2018:1766.

36 Rb. Den Haag 10 april 2018, ECLI:NL:RBDHA: 2018:4066.

37 Hof Amsterdam 20 oktober 2015 (ontucht plegen met patiënt en/of cliënt), ECLI:NL:GHAMS: 2015:5669, TvGR 2019, p. 148, m.nt. Postma. 
niet wegneemt. ${ }^{38}$ Artikel 249 Sr stelt immers, juist gelet op de afhankelijkheidsrelatie, de bescherming van de patiënt voorop. Om dezelfde reden kan evenmin het verweer slagen dat het opzet op ontucht zou ontbreken omdat de handelingen plaatsvonden in het kader van een - experimentele - behandeling. ${ }^{39}$ In een zaak aangaande seksuele handelingen bij een cliënt door een woonbegeleider houdt de rechtbank wel rekening met het feit dat verdachte de seksuele handelingen op verzoek en met instemming van het slachtoffer heeft verricht en dat zij van de seksuele handelingen, zoals zij zelf heeft verklaard, 'blij' werd. Dat betekent echter niet dat er ook naar het oordeel van dit rechtscollege geen sprake is van ontucht in de zin van artikel 249 Sr. De woonbegeleider krijgt een voorwaardelijke gevangenisstraf van drie maanden met een proeftijd van twee jaar opgelegd, met als bijzondere voorwaarde een verbod voor werkzaamheden in de zorg. ${ }^{40}$ De verdachte die ontucht heeft gepleegd met twee vrouwen met een verstandelijke beperking waarvan hij de direct leidinggevende was, is door Rechtbank Zeeland-West-Brabant veroordeeld tot een onvoorwaardelijke gevangenisstraf van zes maanden. ${ }^{41}$ Een onvoorwaardelijke gevangenisstraf is volgens de rechtbank passend omdat verdachte misbruik heeft gemaakt van zijn positie, de kwetsbaarheden van aangeefsters en zijn wetenschap daarvan. Dit deed hij bij verscheidene vrouwen en gedurende een langere periode en dat wordt hem ernstig aangerekend. Rechtbank Limburg heeft op 12 juni 2018 een huisarts vrijgesproken van een tweetal zedendelicten, te weten verkrachting en ontucht. ${ }^{42}$ Verdachte heeft bekend seks met aangeefster te hebben gehad en heeft toegegeven daar-

38 Hof Amsterdam 11 april 2018, ECLI:NL:GHAMS: 2018:1183.

39 Zie ook Hof Den Haag 6 juli 2018, ECLI:NL:GHDHA: 2018:2981 over een poging tot het plegen van ontucht door een huisarts.

40 Rb. Den Haag 28 mei 2018, ECLI:NL:RBDHA: 2018:7741.

41 Rb. Zeeland-West-Brabant 1 oktober 2019, ECLI:NL:RBZWB:2019:4299.

42 Rb. Limburg heeft op 12 juni 2018, ECLI:NL:RBLIM: 2018:5525. mee verschrikkelijk de fout in te zijn gegaan. Maar volgens de rechtbank is er, mede gelet op de wisselende verklaringen van aangeefster, te weinig bewijs voor verkrachting en is de enige seksuele handeling die feitelijk voldoende vaststaat als zodanig nu juist niet door het $\mathrm{OM}$ in de tenlastelegging van ontucht opgenomen. Volgt dus vrijspraak wegens onvoldoende bewijs.

Een ontuchtzaak waarin verschillende aspecten van het (gezondheids)strafrecht naar voren komen betreft het vonnis van Rechtbank Den Haag van 30 januari 2019. ${ }^{43}$ Een 38-jarige huisarts is door de rechtbank veroordeeld tot een onvoorwaardelijke gevangenisstraf van 66 maanden, een tbs-maatregel en ontzetting van het recht om werkzaam te zijn in de gezondheidszorg voor de duur van 126 maanden vanwege diverse zedendelicten (art. 240b, 244, 247, 248 en 249 Sr). De ontucht, een enkele maal ook bestaande uit het seksueel binnendringen van het lichaam, vond zowel plaats met zijn eigen zevenjarige dochter en haar vriendinnetjes, als met minderjarigen die hij in zijn hoedanigheid als waarnemend huisarts 'behandelde' door intieme lichaamsdelen te betasten terwijl dit medisch onnodig en onwenselijk was. Daarnaast had verdachte kinderpornografische foto's gemaakt van zijn dochter en haar vriendinnen en tientallen heimelijke video-opnames van ontklede minderjarige en enkele meerderjarige patiëntes in drie praktijken waar hij als (waarnemend) huisarts werkzaam was. Ten slotte is bij hem een grote hoeveelheid kinderporno aangetroffen die niet door hemzelf vervaardigd is.

De rechtbank rekent het verdachte zwaar aan dat hij in verschillende belangrijke private en maatschappelijke rollen het vertrouwen dat anderen in hem stellen op grove wijze heeft geschonden. Het feit dat het misbruik op deze schaal heeft plaatsgehad, is naar het oordeel van de rechtbank zeer ernstig en zorgwekkend. Het feit dat verdachte geen inzicht heeft willen geven in zijn persoonlijkheid door te weigeren mee te werken aan de onderzoeken daaromtrent (een gekozen en strategische proceshou-

43 Rb. Den Haag 30 januari 2019, ECLI:NL:RBDHA: 2019:701. 
ding), weegt de rechtbank ten nadele mee, net als het feit dat verdachte geen volledige openheid van zaken heeft gegeven in het feitenonderzoek. Verdachte komt volgens de rechtbank 'ontwijkend, verhullend en berekenend' over. Twee deskundigen hebben, ondanks het weigeren mee te werken aan onderzoeken door verdachte, een pedofiele stoornis bij hem vastgesteld 'indien de tenlastegelegde feiten worden bewezen'. De redeneringen en conclusies in het rapport zijn volgens de rechtbank met redenen omkleed, begrijpelijk en navolgbaar. Mede vanwege gebrek aan een andersluidende contra-expertise, sluit de rechtbank bij deze conclusies aan. De rechtbank is van oordeel dat de stoornis van de verdachte en het daaruit voortvloeiende recidiverisico zodanig is dat het vanuit veiligheidsoogpunt onverantwoord is om de verdachte onbehandeld terug te laten keren in de maatschappij en legt mede daarom tbs met dwangverpleging op. Doordat het misdrijven betreft die gericht zijn tegen of gevaar hebben veroorzaakt voor de onaantastbaarheid van het lichaam van een persoon, is sprake van een ongemaximeerde tbs als bedoeld in artikel 38e Sr. Daarnaast krijgt verdachte, die slechts verminderd toerekeningsvatbaar wordt geacht, ook een onvoorwaardelijke gevangenisstraf opgelegd. Bovendien wijst de rechtbank vorderingen tot schadevergoeding van 22 slachtoffers (deels) toe en veroordeelt verdachte om in totaal een bedrag van $€ 16.840,40$ te betalen, bestaande uit zowel immateriële als materiële schade.

Naast deze zaken hebben zich nog twee zaken voorgedaan waarin een hulpverlener in de gezondheidszorg is veroordeeld wegens verkrachting. Dat wil zeggen: het onder dwang seksueel binnendringen van een ander. Er bestaat geen aparte strafbaarstelling of gekwalificeerd delict van verkrachting door iemand die werkzaam is in de gezondheidszorg, maar in de rechtspraak wordt de afhankelijkheidspositie van de patiënt/cliënt ten opzichte van de hulpverlener wel degelijk in strafverzwarende zin meegewogen. De hierboven aangehaalde rechtspraak geeft daarvan blijk. Het vonnis van Rechtbank Oost-Brabant van 26 november 2018 ziet op een behandelaar in de traditionele Chinese geneeskunst die onverhoeds seksuele handelingen, mede bestaande uit het seksueel binnendringen van het lichaam, bij zijn 17-jarige cliënte heeft verricht, terwijl zij zich vanwege een acupunctuur- en massagebehandeling naakt in de behandelruimte in zijn woning bevond. ${ }^{44}$ Verdachte heeft naar het oordeel van de rechtbank ernstig misbruik gemaakt van de lichamelijke integriteit van zijn cliënte, zijn positie als behandelaar en de daaruit voortvloeiende afhankelijkheid van het slachtoffer. Door zijn handelen heeft hij niet alleen het vertrouwen dat het slachtoffer in hem stelde geschaad, maar ook het vertrouwen van het slachtoffer in andere hulpverleners. Een gevangenisstraf van dertig maanden is volgens de rechtbank de enige passende sanctie. Daarvan is de helft onvoorwaardelijk. De andere vijftien maanden zijn voorwaardelijk opgelegd (proeftijd van twee jaar) om verdachte ervan te weerhouden opnieuw strafbare feiten te plegen. De vordering van de benadeelde partij wordt toegewezen met oplegging van de schadevergoedingsmaatregel van artikel $36 \mathrm{f} \mathrm{Sr}$ zodat verdachte $€ 7.500$ immateriële schadevergoeding en $€ 58,80$ materiële schadevergoeding, te vermeerderen met de wettelijke rente, dient te betalen.

Door Hof Arnhem-Leeuwarden is op 6 juni 2019 een 37-jarige alternatief genezer veroordeeld wegens verkrachting van twee zussen van - ten tijde van de gedragingen in 1992 - 13 en 16 jaar oud, ondanks een aanzienlijk tijdsverloop tussen de feiten en aangiftes. ${ }^{45}$ De alternatief genezer had als behandelaar van de vader ook aangeboden zijn gezin te beschermen tegen 'kwade invloeden'. Bij twee gelegenheden wilde hij de dochters alleen, apart van elkaar, in zijn behandelkamer zien. Ze moesten zich uitkleden, hij ging onverhoeds bovenop hen liggen en heeft seksuele gemeenschap met hen gehad. Het hof is van oordeel dat sprake is van dwang; verdachte heeft telkens opzettelijk veroorzaakt dat beide slachtoffers niet in staat waren aan zijn handelingen weerstand te bieden of zich daaraan te onttrekken. Hij heeft misbruik gemaakt van zijn psychische overwicht als alternatief gene-

$\begin{array}{lllll} & \text { Rb. Oost-Brabant 26 november } & \text { 2018, } \\ \text { ECLI:NL:RBOBR:2018:5843. } & & & \\ 45 \text { Hof Arnhem-Leeuwarden } & 6 \text { juni } & 2019, \\ \text { ECLI:NL:GHARL:2018:5276. } & & & \end{array}$


zer en het grote leeftijdsverschil. Het hof rekent het hem bovendien zeer aan dat hij misbruik heeft gemaakt van de Javaans- Surinaamse culturele gebruiken (waarbij het niet gebruikelijk is om over seksualiteit te praten), de gezondheidssituatie van de vader van de meisjes en het vertrouwen dat de familie hem gaf. Het hof veroordeelt de genezer tot een gevangenisstraf van twee jaar, waarvan een jaar voorwaardelijk met een proeftijd van twee jaar. Opvallend is de beslissing ten aanzien van de schadevergoeding. Vanwege het verstrijken van de verjaringstermijn moeten de slachtoffers in hun vordering als de benadeelde partij niet-ontvankelijk worden verklaard. De maatregel van artikel $36 \mathrm{f} \mathrm{Sr}$ kan niet worden toegepast omdat die ten tijde van de bewezen gedragingen nog niet bestond. Daarom legt het hof aan de verdachte als bijzondere voorwaarde bij het voorwaardelijk strafdeel op het vergoeden van de geleden schade (in totaal zo'n $€ 11.000)$ aan de slachtoffers. Een creatieve 'omleiding' waartegen letter noch strekking van de wet zich onzes inziens in dit geval verzetten.

\section{Strafbaarheid afbreking zwangerschap door huisarts}

Een van de kwesties die de afgelopen kroniekperiode heeft gespeeld is in hoeverre een huisarts strafrechtelijk vervolgd kan worden voor het verstrekken van een zogenoemde abortuspil. Sinds de inwerkingtreding van de Wet afbreking zwangerschap (Waz) in 1984 is abortus alleen dan niet strafbaar indien de behandeling is verricht door een arts in een vergunninghoudend ziekenhuis of abortuskliniek. ${ }^{46}$ In dat kader is de uitspraak van Rechtbank Den Haag op 6 september 2017 het bespreken waard. ${ }^{47}$ Het betreft de toetsing door de civiele rechter van de juistheid van het beleidsstandpunt van de minister van VWS en de Inspectie over de zogenoemde 'abortuspil'. De toepassing van een

46 Stb. 1981, 257, inwerkingtreding 1 november 1984 (Stb. 1984, 218).

47 Rb. Den Haag 6 september 2017, ECLI:NL:RBDHA: 2017:10060, GJ 2017/157. medicamenteuze overtijdbehandeling door het voorschrijven van de abortuspil door huisartsen is volgens de minister en de inspectie strafbaar op grond van artikel 296 Sr. Volgens o.a. Women on Waves en de stichting Proefprocessenfonds Clara Wichmann is dat standpunt onjuist, want het is in strijd met de wetsgeschiedenis van de Waz. Terecht overweegt de civiele rechter geen taak te hebben met betrekking tot een strafrechtelijke beoordeling in een individueel geval, noch ten aanzien van het vervolgingsbeleid van het Openbaar Ministerie ter zake. Maar, 'de bevoegdheid van de strafrechter ten aanzien van de beoordeling van artikel $296 \mathrm{Sr}$ [is] geen exclusieve in die zin dat een strafrechtelijke procedure op initiatief van het Openbaar Ministerie moet worden afgewacht om de juistheid van het beleidsstandpunt van de minister van VWS en de IGZ aan rechterlijke toetsing te kunnen onderwerpen'. De rechtbank acht het beleidsstandpunt niet onverenigbaar met de Waz. Uit de parlementaire geschiedenis van artikel 296 Sr blijkt niet dat de wetgever de uitdrukkelijke bedoeling heeft gehad de overtijdbepaling wel onder artikel 296 Sr te doen vallen. Dat betekent echter volgens de rechtbank ook weer niet dat degene die een dergelijk middel voorschrijft buiten een ziekenhuis of kliniek, niet strafbaar is op grond van artikel $296 \mathrm{Sr}$. Ten tijde van de totstandkoming van de Waz en artikel 296 Sr was er nog geen middel geregistreerd waarmee een medicamenteuze overtijdbehandeling kon worden toegepast. Het betrof destijds een instrumentele behandeling die alleen in een ziekenhuis of kliniek kon plaatsvinden. Bovendien kon toen nog niet van tevoren worden vastgesteld of de vrouw inderdaad zwanger was. Vanwege verfijning van de testtechniek kan dat tegenwoordig in een eerder stadium. De rechtbank overweegt dat het de bedoeling van de wetgever is geweest dat artsen die overtijdbehandelingen toepassen buiten een ziekenhuis of kliniek met een Waz-vergunning strafbaar zijn op grond van artikel 296 Sr. Een huisarts mag derhalve (vooralsnog) zelf geen zwangerschapsafbreking verrichten. Wellicht komt hier in de nabije toekomst verandering in. Door GroenLinks en de PvdA is in februari 2018 een wetsvoorstel ingediend tot wijzi- 
ging van de Waz en het Wetboek van Strafrecht om vrouwen de keuze te geven een ongewenst zwangerschap in een vroeg stadium af te breken met medicatie bij een 'vertrouwde hulpverlener dicht bij huis. ${ }^{48}$

\section{Euthanasie}

In deze kroniekperiode blijkt wederom dat euthanasie geen rustig bezit is. De discussie ging met name over euthanasie bij patiënten met dementie op basis van een schriftelijke wilsverklaring en euthanasie bij patiënten met een psychiatrische aandoening, hoewel slechts $1 \%$ van de meldingen die de Regionale Toetsingscommissies Euthanasie (RTE) dienen te beoordelen (een van) die categorieën betreft. In 2018 was voor het eerst een lichte daling te zien in het totaal aantal euthanasiemeldingen: van 6.585 in 2017 naar 6.126 in $2018 .{ }^{49}$ Door sommigen is die daling in verband gebracht met het besluit van het Openbaar Ministerie om in vijf zaken waarin de RTE tot het oordeel 'onzorgvuldig' was gekomen, tot strafrechtelijk onderzoek over te gaan. ${ }^{50}$

Ter ondersteuning van de uitvoeringspraktijk heeft de RTE in het voorjaar van 2018 de EuthanasieCode 2018 uitgebracht. Door de Nederlandse vereniging voor Psychiatrie is in het najaar van 2018 de Richtlijn levensbeëindiging op verzoek bij patiënten met een psychische stoornis gepubliceerd. Op 4 september 2019 is de Stichting Levenseindekliniek (SLK) omgedoopt tot het Expertisecentrum Euthanasie.

In augustus 2018 heeft minister De Jonge van Volksgezondheid, Welzijn en Sport over euthanasie en de Wet zorg en dwang gezegd dat het vasthouden of 'fixeren' van de patiënt voorafgaand aan de uit-

Kamerstukken II 2017/18, 34891, 7 bevat de MvT zoals gewijzigd n.a.v. het advies van de Raad van State.

49 Zie het Jaarverslag 2018 van de Regionale Toetsingscommissies Euthanasie, te raadplegen via www.euthanasiecommissie.nl.

50 In een zaak is het OM overgegaan tot strafrechtelijke vervolging. De strafzaak tegen de arts is inmiddels afgesloten. Twee zaken werden geseponeerd, twee onderzoeken lopen nog. voering van de euthanasie met als doel om te voorkomen dat de patiënt zich zal verzetten geen onderdeel is en mag zijn van de uitvoering van een euthanasie. De minister schrijft dat het toepassen van dwang bij euthanasie pertinent niet in overeenstemming is met een verantwoorde uitvoeringspraktijk. Alleen in het kader van de Wet zorg en dwang bestaan uitzonderingen op de vrijwilligheid en dus op het handelen zonder toestemming. Onvrijwillige zorg mag slechts worden gebruikt als uiterste middel..$^{51}$ Over de uitvoering van de euthanasie in een concreet oordeel van een RTE, te weten oordeel 2016-85, kon de minister geen uitspraken doen, omdat deze casus op dat moment onderwerp was van een strafrechtelijk onderzoek.

Het is in die zaak waarin het Openbaar Ministerie voor het eerst sinds de inwerkingtreding van de Wet toetsing levensbeëindiging op verzoek en hulp bij zelfdoding (WTL) tot vervolging van een arts is overgegaan naar aanleiding van het oordeel van de RTE dat de specialist ouderengeneeskunde niet overeenkomstig de zorgvuldigheidseisen heeft gehandeld in een geval van euthanasie bij een patiente met vergevorderde dementie. Dat leidde tot het recente, de aandacht trekkende vonnis van Rechtbank Den Haag. ${ }^{52}$ De feiten in de zaak zijn uitgebreid aan bod gekomen in onze vorige kroniek. Eerder was de tuchtrechter al tot de conclusie gekomen dat de arts niet conform de regels had gehandeld. Het Regionaal Tuchtcollege heeft haar een berisping gegeven. ${ }^{53}$ Het Centraal Tuchtcollege

51 Brief van 28 augustus 2018 van minister Hugo de Jonge betreffende de toezegging EK over euthanasie en Wet zorg en dwang, kenmerk 1403399-179816PG.

52 Rb. Den Haag van 11 september 2019, ECLI:NL:RBDHA:2019:9506. Zie over deze zaak en de problematiek inmiddels M.J.J. de Bontridder, 'Wat gaat voor: mijn wilsbekwame ik of mijn demente ik?', NJB 2019/2267 en de annotatie van Schalken (G) 2019/142).

53 RTG Den Haag 24 juli 2018, ECLI:NL:TGZRSGR: 2018:165, 2018-033. Zie G.A. den Hartogh, 'De wil van de wilsonbekwame patiënt', TvGR 2018, p. 431-454 en T.J. Matthijssen, 'Euthanasie bij gevorderde dementie: een belangrijke uitspraak', TvGR 2019, p. 46-58. 
heeft het bij een waarschuwing gehouden. ${ }^{54}$ Hoewel in de media commentaar is geuit op de combinatie van een tuchtrechtelijke en strafrechtelijke procedure voor de arts, is het tuchtrecht geen belemmering om alsnog een strafrechtelijke procedure te starten. De tuchtrechter overweegt ter zake: 'Het tuchtrecht richt zich op de kwaliteit van de gezondheidszorg. Het strafrecht richt zich op de (strafrechts)handhaving. Dit zijn wezenlijk verschillende dingen. ${ }^{55}$ Hoewel het voor de arts wellicht anders voelt, is er juridisch gezien geen sprake van een tweede strafvervolging en geen sprake van schending van het ne-bis-in-idembeginsel. Het verweer dat niet meer kon of behoorde te worden vervolgd werd door de strafrechter dan ook verworpen. Wel is er idealiter sprake van afstemming, zoals bepaald in het Samenwerkingsprotocol gezondheidszorg van het $\mathrm{OM}$ en de Inspectie. ${ }^{56}$

Het Openbaar Ministerie had primair euthanasie en subsidiair moord ten laste gelegd. De kwalificatie 'moord' klinkt daarbij zwaar, maar dat is (zo men wil: nu eenmaal) wat er volgens het Wetboek van Strafrecht aan de orde is, in geval niet duidelijk is of sprake is van het uitdrukkelijk en ernstig verlangen als bedoeld in artikel 293 lid 1 Sr. De officier van justitie concludeerde, vanwege het ontbreken van een deugdelijk verzoek tot vrijspraak ten aanzien van euthanasie, en schuldigverklaring ter zake van moord, maar eiste geen straf tegen de verpleeghuisarts (art. 9a Sr). Door de rechtbank is de arts ontslagen van alle rechtsvervolging. De rechtbank acht artikel 293 lid 1 Sr van toepassing; zij gebruikt daartoe de schriftelijke wilsverklaring als het in die delictsomschrijving bedoelde verlangen. De arts heeft naar het oordeel van de rechtbank volgens de

CTG 19 maart 2019 (wilsbekwaamheid en euthanasie) m.nt. E. Pans, TvGR 2019, p. 276-292.

55 RTG Den Haag 24 juli 2018, ECLI:NL:TGZRSGR 2018:165, onder 5.2. Zie ook CTG 19 maart 2019, ECLI:NL:TGZCTG:2019:68, onder 3 en 4.5: het Centraal Tuchtcollege sluit zich aan bij hetgeen het Regionaal Tuchtcollege ter zake heeft overwogen.

56 Samenwerkingsprotocol OM en IGZ bij medische strafzaken, 2015. Zie www.rijksoverheid.nl/ documenten/richtlijnen/2015/06/30/

samenwerkingsprotocol-gezondheidszorg-2015. zorgvuldigheidseisen van artikel 2 WTL gehandeld. Het bewezen feit, euthanasie, is daarmee naar het oordeel van de rechtbank op grond van artikel 293 lid 2 Sr niet strafbaar nu verdachte haar levensbeëindigend handelen bovendien (het is een apart bestanddeel van art. 293 lid 2 Sr) gemeld heeft. Anders dan de officier van justitie is de rechtbank van mening dat op verdachte, gegeven de diep demente toestand waarin patiënte zich inmiddels bevond, niet de plicht rustte te informeren naar een actuele levens-of stervenswens van de patiënt. Evenmin ziet de rechtbank in waarom de verdachte met deze wilsonbekwame en diep demente patiënte had moeten overleggen over het moment dat en de wijze waarop de euthanasie zou worden uitgevoerd. Aan dit juridisch oordeel voegt de rechtbank een overweging toe waarin zij haar mening over de tenlastelegging niet onder stoelen of banken lijkt te steken door op te merken 'dat zij zich kan voorstellen dat het een hard gelag is voor de verdachte dat zij zich geconfronteerd ziet met een beschuldiging van moord terwijl zij - in de ogen van de officier van justitie - heeft voldaan aan vrijwel alle toepasselijke zorgvuldigheidseisen en haar volgens de officier van justitie van het overtreden van één belangrijke zorgvuldigheidseis slechts een beperkt verwijt kan worden gemaakt omdat die eis onvoldoende duidelijk en kenbaar in de wet was neergelegd. Onder zulke omstandigheden doet een beschuldiging van moord geen recht aan het integere en transparante handelen van de verdachte.' Het is enigszins gissen naar de precieze betekenis van deze overwegingen, in het bijzonder omdat de rechtbank, gegeven haar oordeel, nu juist niet aan het subsidiair ten laste gelegde misdrijf van moord kon toekomen. Voor de arts is definitief een eind gekomen aan haar proces. Het Openbaar Ministerie is het niet eens met de uitspraak van de rechtbank, maar heeft toch afgezien af van hoger beroep. Het OM heeft de procureurgeneraal van de Hoge Raad verzocht om cassatie in het belang der wet in te stellen, die daartoe inderdaad bereid bleek. De vordering van de P-G daartoe wordt naar verwachting in de maand december van 
dit jaar ingesteld. ${ }^{57}$ In afwachting van het arrest van de Hoge Raad schort het Openbaar Ministerie de beoordeling van andere lopende euthanasiezaken op voor zover in die zaken dezelfde rechtsvragen aan de orde zijn. ${ }^{58}$

In Nederland bestaat vooralsnog geen wettelijke regeling voor levensbeëindiging bij kinderen in de leeftijdsgroep 1-12 jaar, hetgeen overigens - vanuit strafrechtelijk oogpunt bezien - de mogelijkheid dat in voorkomende gevallen een gegrond beroep op overmacht in de zin van noodtoestand (art. $40 \mathrm{Sr}$ ) kan worden gedaan, niet uitsluit. In september 2019 is het onderzoek Medische beslissingen rond het levenseinde bij kinderen (1-12) aangeboden aan de Tweede Kamer. ${ }^{59}$ De onderzoekers concluderen dat er (1) geen aanwijzingen zijn dat actieve levensbeëindiging en euthanasie bij kinderen (1-12) momenteel voorkomt, (2) artsen ter zake wel een grijs gebied beschrijven tussen palliatieve sedatie en actieve levensbeëindiging, (3) gevallen van ondraaglijk en uitzichtloos lijden voorkomen bij kinderen, en artsen niet altijd in staat zijn om dit lijden weg te nemen en (4) onder een beperkt deel van de ouders en artsen duidelijke behoefte aan verruiming van de mogelijkheid van actieve levensbeëindiging bij kinderen is. De onderzoekers bevelen aan basiskennis van kinderartsen over palliatieve zorg en bekendheid van en het draagvlak voor het artsen-steunpunt van het landelijk kenniscentrum kinderpalliatieve zorg te vergroten. Daarnaast dient het onderscheid tussen palliatieve sedatie en actieve levensbeëindiging voor kinderartsen verhelderd te worden, dient bestaande regelgeving van actieve levensbeëindiging bij kinderen te worden verhelderd en dient te worden nagegaan of nadere regulering daar-

www.rechtspraak.nl/Organisatie-en-contact/ Organisatie/Hoge-Raad-der-Nederlanden/Nieuws/ Paginas/PG-bij-de-Hoge-Raad-voornemens-cassatiein-het-belang-der-wet-in-te-stellen-ineuthanasiezaak-.aspx. www.om.nl/onderwerpen/euthanasie/@106753/ hoge-raad/.

59 www.rijksoverheid.nl/documenten/rapporten/ 2019/09/28/medische-beslissingen-rond-hetlevenseinde-bij-kinderen-1-12. van aangewezen is. Minister De Jonge heeft laten weten dat de euthanasiewet per definitie niet aangepast wordt om actieve levensbeëindiging mogelijk te maken voor kinderen tussen de 1 en 12 jaar, omdat deze kinderen wilsonbekwaam zijn en er niet gesproken kan worden over euthanasie. Wel wil hij gaan bekijken wat er moet gebeuren om ouders en artsen meer houvast te bieden rondom actieve levensbeëindiging. ${ }^{60}$

\section{Hulp bij zelfdoding}

Rechtbank Limburg heeft in haar vonnis van 26 februari 2019 een 48-jarige man die geen arts is, veroordeeld tot een voorwaardelijke gevangenisstraf van drie maanden, met een proeftijd van twee jaar vanwege hulp bij de zelfdoding van zijn vader. ${ }^{61}$ Deze straf dient volgens de rechtbank een generaalpreventief doel. De rechtbank wil duidelijk maken dat het buiten de wettelijke kaders hulp verlenen bij zelfdoding niet straffeloos kan blijven, ook al gebeurt het met de beste bedoelingen. De vader van verdachte was ervan overtuigd dat hij kanker had, wilde een eind aan zijn leven maken, was niet in staat de zelfdoding alleen uit te voeren maar weigerde een arts te raadplegen, zowel wat betreft de diagnose, eventuele behandeling als hulp bij zelfdoding. Verdachte heeft een installatie in elkaar gezet die zijn vader vervolgens heeft gebruikt voor zijn zelfdoding. Een dag later heeft verdachte aangifte gedaan bij de politie. Naar het oordeel van de rechtbank heeft verdachte zich alleen laten leiden door de doodswens van zijn vader en daarbij niet betrokken dat zijn handelen strafbaar was. Als volwassen man had van hem verwacht kunnen worden dat hij kritischer zou staan tegenover de doodswens van zijn vader, maar zeker ook tegenover diens wens dat verdachte hem daarbij behulpzaam zou moeten zijn. Niet alleen omdat hulp bij zelfdoding

60 www.medischcontact.nl/nieuws/laatste-nieuws/ nieuwsartikel/de-jonge-euthanasiewet-nietuitbreiden-voor-kinderen.htm.

61 Rb. Limburg 26 februari 2019, ECLI:NL:RBLIM: 2019:1740. 
in Nederland als een misdrijf geldt, maar in deze zaak eens te meer aangezien zijn vader al jarenlang geen arts meer had bezocht en de verdachte ook niet met anderen, zoals familie of zijn eigen arts, heeft overlegd over wat een juiste manier zou zijn om met het lijden van zijn vader en zijn doodswens om te gaan. Zowel het beroep op overmacht in de zin van noodtoestand als het beroep op psychische overmacht wordt verworpen.

Het arrest van de Hoge Raad van 16 april 2019, is, althans in Nederland, de laatste in de reeks 'Heringa', de 'niet-arts' die zijn 99-jarige moeder heeft geholpen bij haar zelfdoding. ${ }^{62}$ Door de rechtbank is hij in 2013 schuldig verklaard zonder oplegging van straf of maatregel. ${ }^{63}$ Hof Arnhem-Leeuwarden heeft in 2015 geoordeeld dat verdachte een beroep toekwam op overmacht in de zin van noodtoestand. ${ }^{64}$ De A-G bij de Hoge Raad concludeerde tot verwerping van het beroep, maar de Hoge Raad heeft bij arrest van 14 maart 2017 het arrest van het hof vernietigd wat betreft het gegeven ontslag van alle rechtsvervolging. ${ }^{65}$ Door Hof Den Bosch is Heringa vervolgens in 2018 veroordeeld tot een voorwaardelijke gevangenisstraf van zes maanden. ${ }^{66}$ Met de beslissing van de Hoge Raad van 16 april 2019 is die veroordeling definitief.

De Hoge Raad merkt daarbij op: 'Voor zover het middel berust op de opvatting dat ingeval door een verdachte die geen arts is, een beroep is gedaan op overmacht in de zin van noodtoestand, de rechter bij de beoordeling van dat verweer nooit omstandigheden mag betrekken die ook tot uitdrukking komen in de zorgvuldigheidseisen als bedoeld in art. 293, tweede lid, Sr, vindt deze opvatting geen steun in het recht. Die voor een arts geldende

62 HR 16 april 2019, ECLI:NL:HR:2019:598, NJ 2019/336.

63 Rb. Gelderland 22 oktober 2013, ECLI:NL:RBGEL: 2013:397.

64 Hof Arnhem-Leeuwarden 13 mei 2015, ECLI:NL:GHARL:2015:344.

65 HR 14 maart 2017, ECLI:NL:HR:2017:418, NJ 2017/269.

66 Hof Den Bosch 31 januari 2018, ECLI:NL:GHSHE: 2018:345. zorgvuldigheidseisen zijn als zodanig niet van toepassing in een geval als het onderhavige waarin de verdachte de - cruciale - hoedanigheid van arts mist (...). Het is evenwel niet uitgesloten dat een omstandigheid die in het kader van die zorgvuldigheidseisen relevant is, ook van belang kan zijn voor de beoordeling van een - in een geval als het onderhavige slechts bij hoge uitzondering te aanvaarden beroep op overmacht in de zin van noodtoestand, bijvoorbeeld bij de beoordeling van eisen van proportionaliteit en subsidiariteit.'

Vooralsnog is er geen wettelijke regeling voor hulp bij zelfdoding door een niet-arts respectievelijk aan personen die een doodswens hebben maar geen medisch classificeerbare ziekte. Pia Dijkstra (D66) is voornemens begin 2020 een wetsvoorstel Voltooid Leven in te dienen, ongeacht de uitkomst van het onderzoek van Els van Wijngaarden van de Universiteit voor Humanistiek naar de omvang van de groep ouderen die zeggen geen levensperspectief te ervaren, maar niet voldoen aan de criteria van de WTL. ${ }^{67}$ Daarmee geldt net als de vorige keer: wordt ongetwijfeld vervolgd. Voor de geïnteresseerde lezer vermelden we nog dat dit najaar de uitspraak wordt verwacht van het Duitse Bundesverfassungsgericht (BVerfG) over de (omstreden) strafbepaling van artikel 217 StGB inzake het beroepsmatig bevorderen van hulp bij zelfdoding. Wel maakte de Duitse strafrechter in de verslagperiode (definitief) een einde aan strafbaarheid ter zake van hulp bij zelfdoding van een arts via de 'U-bocht' van strafbaarheid ter zake van het doden door nalaten of verlaten van hulpbehoevenden. ${ }^{68}$

67 www.medischcontact.nl/nieuws/laatste-nieuws/ nieuwsartikel/d66-komt-snel-metvoltooidlevenwet.htm.

68 We kunnen het niet nalaten; wie de mondelinge uiteenzetting van de verwerping van het beroep van het OM tegen de vrijspraak van de beide artsen door het Bundesgerichtshof ziet c.q. aanhoort, krijgt een prachtig, principieel getoonzet college Duits gezondheidsstrafrecht. Zie www.swr.de/swraktuell/bw/ karlsruhe/bgh-sterbehilfe/-/id=1572/did=24369802/ nid=1572/8yykvz/index.html. 


\section{Overige zaken en thema's; varia}

Nogal wat strafbepalingen in bijzondere wetten op deelgebieden van het gezondheidsrecht verwijzen naar nadere normering of definities in aan andere wettelijke bepalingen. Wijzingen daarin of rechterlijke beslissingen ter zake hebben dan consequenties voor de toepassing van dergelijke strafbepalingen. We noemen uit de kroniekperiode twee voorbeelden. Op het gebied van wetgeving blijven de verbodsbepalingen in de Embryowet overeind nu het kabinet, na advies van de Raad van State over een voornemen tot wetswijziging, heeft afgezien van de eerder voorgenomen aanpassingen van die verboden, bijvoorbeeld ten aanzien van het kweken van embryo's voor wetenschappelijk onderzoek. ${ }^{69}$ Uit de rechtspraak noemen wij HR 9 april 2019, NJ 2019/439. ${ }^{70}$ De (inmiddels gewezen) verdachte was eerder onherroepelijk veroordeeld wegens het bereiden en afleveren van tabletten $\mathrm{MCPP}$, een synthetische drug. Hij was vervolgd voor overtreding van artikel 2.3 van de Wet op de Geneesmiddelenvoorziening, een economisch delict. Inmiddels, dus na deze onherroepelijke veroordeling, moet op grond van een latere beslissing van het EU-Hof van Justitie worden aangenomen dat daarbij van een verkeerd begrip 'geneesmiddel' in de zin van een EU-richtlijn is uitgegaan. ${ }^{71}$ Daarmee is de grondslag onder de strafbaarheid van de gedraging van de gewezen verdachte alsnog vervallen. Het probleem is dat het Nederlands recht niet voorziet in de mogelijkheid om op deze grond de onterechte veroordeling te

Zie de brief van de minister van Volksgezondheid, Welzijn en Sport van 28 augustus 2018, en het bijgevoegde nader rapport, strekkende tot het niet indienen van het voorstel tot wijziging van de Embryowet (Stcrt. 2018, 42606). We attenderen ook nog op de Wet Verbeteren patiëntgerichte zorg en opnemen wettelijke regeling voor inzagerecht medisch dossier van overleden patiënt, Stb. 2019, 224 (Kamerstukken 34994; zie voor de (verspreide) inwerkingtreding Stb. 2019,284 ) ten aanzien van het recht op verstrekken van inzage na overlijden in geval van een vermoeden van een medische fout.

70 HR 9 april 2019, ECLI:NL:HR:2019:546, NJ 2019/439.

71 Het gaat om HvJ EU 10 juli 2014, C-358/13, ECLI:EU:C:2014:2060. herzien. Mogelijk kan uit de strafzaak de aanwijzing worden afgeleid om wetten op het gebied van de gezondheidszorg niet te gemakkelijk in te zetten voor de drugsbestrijding of voor andere doeleinden buiten die gezondheidszorg.

In de vorige Kroniek bespraken wij een zaak waarin een kinderarts was veroordeeld tot een geldboete van $€ 2.500$ wegens dood door schuld omdat zij had nagelaten tijdig een CT-scan te laten maken van een 10 -jarige patiënt. ${ }^{72}$ Indien de scan wel was gemaakt, had tijdig ingegrepen kunnen worden waardoor het leven van de patiënt naar alle waarschijnlijkheid gered zou kunnen zijn. In hoger beroep komt Hof Den Bosch tot dezelfde strafoplegging en motivering. ${ }^{73}$ Anders dan was gevorderd door de advocaat-generaal (en in eerste instantie door de officier van justitie), heeft het hof niet een zwaardere gradatie van (gewone) schuld (te weten: 'grove schuld') bewezenverklaard dan de rechtbank. Het hof merkt op dat enerzijds voorkomen moet worden dat artsen zich door de vrees voor strafrechtelijke vervolging niet meer vrij voelen te doen wat zij in het belang van hun patiënt achten. Anderzijds kunnen zich omstandigheden voordoen, zoals de aard en de duur van het handelen van een arts, die strafrechtelijke bemoeienis met medisch handelen kunnen rechtvaardigen, zoals blijkens het oordeel van de hof ter zake het geval is. Schalken vraagt zich in zijn noot af of een tuchtrechtelijke afdoening niet meer voor de hand had gelegen, aangezien de ernst van het gevolg in het strafrecht geen invloed mag hebben op de mate van schuld. ${ }^{74}$

Rechtbank Amsterdam heeft op 17 september 2019 een taakstraf opgelegd van 80 uren aan een 60-jarige man wegens valsheid in geschrift (art. $225 \mathrm{Sr}$ ). ${ }^{75} \mathrm{De}$ man, die zelf als arts in het BIG-register geregis-

72 Rb. Limburg 7 maart 2017, ECLI:NL:RBLIM: 2017:2076.

73 Hof Den Bosch 11 juli 2019, ECLI:NL:GHSHE: 2019:2406.

74 Hof Den Bosch 11 juli 2019, ECLI:NL:GHSHE: 2019:2406, GJ 2019/124 m.nt. Schalken.

75 Rb. Amsterdam 17 september 2019, ECLI:NL:RBAMS:2019:6797. 
treerd staat, had door het receptenpapier van zijn psychiater te gebruiken, valselijk recepten opgemaakt voor zichzelf. Het leek voor de apotheek alsof de recepten van de behandelend psychiater van verdachte afkomstig waren. Verdachte heeft niet alleen zijn eigen handtekening op de recepten gezet, maar ook tweemaal de handtekening van zijn psychiater. Dat draagt naar het oordeel van de rechtbank bij aan de overtuiging dat verdachte opzettelijk de verkeerde indruk wilde wekken bij de apotheek. De rechtbank benadrukt dat verdachte door zijn handelen het vertrouwen dat in het algemeen in het maatschappelijke verkeer moet kunnen worden gesteld in het gebruik van recepten op basis waarvan apothekers medicatie verstrekken ernstig heeft geschaad. Daar komt nog bij dat hij zich daar, nu hij zelf arts was, bewust van had moeten zijn.

Wij maakten in de vorige kroniek reeds melding van een niet-BIG-geregistreerde die naar eigen zeggen sinds 1999 honderden verslaafden met ibogaïne 'behandelde'. Voor een aantal incidenten, zoals een patiënt die door het gebruik van ibogaïne een hartstilstand kreeg en blijvend gehandicapt raakte, is de verdachte in 2015 reeds veroordeeld tot een gevangenisstraf. ${ }^{76}$ In 2019 is zij wederom veroordeeld, ditmaal vanwege het overlijden van een Zweedse vrouw na haar 'behandeling' met ibogaïne in 2017. ${ }^{77}$ Verdachte had 112 gebeld toen het slachtoffer onwel was geworden, maar heeft daarbij verzwegen dat het middel was toegediend. Na de melding is ze ervandoor gegaan en in Duitsland aangehouden en overgeleverd op grond van een Europees aanhoudingsbevel. Verdachte heeft zich naar het oordeel van de rechtbank onder andere schuldig gemaakt aan doodslag (art. $287 \mathrm{Sr}$ ) het in hulpeloze toestand achterlaten van het slachtoffer (art. 255 en 257 Sr) en overtreding van artikel 96 Wet BIG. De rechtbank houdt bij het bepalen van de strafmaat

76 Hof Arnhem-Leeuwarden 9 oktober 2015, ECLI:NL:GHARL:2015:7562. Dit arrest is door de Hoge Raad bevestigd op 4 april 2017, ECLI:NL:HR: 2017:585.

77 Rb. Midden-Nederland 10 april 2019, ECLI:NL:RBMNE:2019:1448. rekening met het feit dat deze fatale afloop het gevolg is geweest van de volstrekt onverantwoordelijke wijze waarop verdachte haar praktijk bleef voeren. Voorts houdt de rechtbank er in hoge mate rekening mee dat verdachte zich niet meer om het slachtoffer heeft bekommerd toen zij onwel werd en met het feit dat het verdachte nog altijd een onverminderd groot geloof heeft in ibogaine, zodat de kans op herhaling als groot kan worden aangemerkt. Alleen een onvoorwaardelijke gevangenisstraf van een aanzienlijke duur, te weten acht jaar, doet volgens de rechtbank recht aan de ernst van de feiten en de omstandigheden waaronder deze zijn gepleegd. Volgens de rechtbank is niet aan de eisen voor het kunnen toewijzen van shockschade voldaan. ${ }^{78}$ Shockschade dient te worden onderscheiden van affectieschade; dat laatste kan slechts voor strafbare feiten die zijn gepleegd na 1 januari 2019. De rechtbank wijst wel de vordering van de benadeelde partij toe wat betreft de materiële schade.

\section{Slotbeschouwing}

De veelheid en verscheidenheid aan zaken in deze Kroniek bevestigt (wederom) dat binnen het gezondheidsrecht en de gezondheidszorg de raakvlakken met verschillende aspecten van het strafrecht de laatste jaren in snel tempo zijn geïntensiveerd.

De strafzaak die er in deze kroniekperiode uitspringt, betreft de zaak tegen de specialist ouderengeneeskunde vanwege euthanasie bij dementie; de eerste zaak onder de WTL waarin een arts vervolgd werd. Die zaak is daarmee uniek, nog daargelaten de discussie over het vervolg. Maar er is meer.

Traditioneel zorgen strafzaken waarin een arts in de beroepspraktijk (mogelijk) strafbare feiten begaat, zoals de 'Haagse borstendokter' voor de nodige

78 De rechtbank sluit wat betreft de criteria voor de toekenning van immateriële schade in de vorm van shockschade aan bij de vaste jurisprudentie van de Hoge Raad: HR 22 februari 2002, ECLI:NL:HR: 2002:AD5356, NJ 2002/240 en HR 9 oktober 2009, ECLI:NL:HR:2009:BI8583, NJ 2010/387. 
ophef in de media. Aangezien ook alternatieve genezers onder de Wet BIG kunnen vallen, grijpen groepen die 'kwakzalverij' willen bestrijden ook gemakkelijk naar het strafrecht. Het aantal ontuchtzaken door hulpverleners is deze kroniekperiode opvallend. Dit zijn evident strafbare feiten die als zodanig niets met gezondheidszorg te maken hebben. Tegelijkertijd zorgen deze zaken ervoor dat, zeker voor de buitenwereld, strafrecht des te gemakkelijker de gezondheidszorg wordt ingezogen.

Binnen de gewone, dagelijkse gang van zaken in de medische wereld kunnen ook zaken fout gaan, met in enkele gevallen de dood van de patiënt of zwaar lichamelijk letsel bij de patiënt als gevolg. De buitenwereld, de patiënt of diens nabestaanden, vragen dan al snel om genoegdoening, om schadevergoeding en om het 'aanpakken' van deze dokter en wel onmiddellijk en met de nodige gestrengheid. Dan ligt een aangifte, een roep om - in elk geval - onderzoek van de zaak via het strafrecht al snel voor de hand, al is het maar omdat strafvervolging vaak ook een eenvoudige weg is om aan schadevergoeding te komen.

De traditionele, in de theorie wel bepleite terughoudendheid van het strafrecht verkeert door dergelijke ontwikkelingen eerder in het omgekeerde: het strafrecht biedt een betrekkelijk gemakkelijk in te zetten systeem van onderzoek naar gedragingen van artsen. Deze 'drang' verklaart de snelle uitholling van de reikwijdte van het medisch beroepsgeheim dat - als men alleen het Wetboek van Strafvordering leest - absoluut is. Wie de rechtspraak kent, weet beter. Als de arts nadrukkelijker in het vizier van het strafrechtelijke systeem van onderzoek geraakt, kan het niet uitblijven of dat vizier gaat zich ook richten op de instelling van gezondheidszorg waarbinnen de arts werkt, zoals de Oost-Brabantse GGZ-instelling heeft ondervonden.

Het strafrecht en zijn onderzoeksmogelijkheden worden bovendien steeds vaker nadrukkelijk ingezet om te controleren of vermoedens van meer systematisch onjuist handelen zouden kunnen kloppen. De nadrukkelijke inzet van het strafrecht bij de bestrijding van 'fraude in de gezondheidszorg', ook een thema van grote politieke aandacht, is daarvan een voorbeeld. Alleen al het gebruik van het woord 'fraude' suggereert de drang om daartegen 'uiteraard' met alle middelen op te treden.

Het strafrechtelijke deel van het gezondheidsrecht omvat aldus veel verschillende aspecten. Dat uit zich in een variëteit aan strafzaken in deze kroniek. Gemeenschappelijk aan een aantal rechterlijke uitspraken die in het bovenstaande zijn besproken, is dat de rechter nogal eens mogelijkheden zoekt en gebruikt om de verdachte de verdere beroepsuitoefening onmogelijk te maken om recidive en dus nieuwe slachtoffers te voorkomen. Blijkens het overzicht van rechtspraak worden daartoe verschillende juridische varianten gebruikt: een kale(re) voorwaardelijke straf, al dan niet aangevuld met bijzondere voorwaarden en soms veroordeling tot de bijkomende straf van die strekking, waarbij ook artikel 96 lid 3 Wet BIG een rol speelt. Zie ook artikel 98a van die wet. De tijdige en snelle ontzetting uit het beroep wordt kennelijk belangrijk gevonden, in welk kader artikel 96a en 96b Wet BIG ook in een voorlopige voorziening voorzien. In andere gevallen moet voor die bijkomende straf eerder op het Wetboek van Strafrecht worden gekoerst. Misschien vraagt een en ander op termijn wel om een meer eenvormige regeling. 